\title{
Assessment of heavy metal contamination in soil due to leachate migration from an open dumping site
}

\author{
S. Kanmani $\cdot$ R. Gandhimathi
}

Received: 12 September 2012/Accepted: 7 December 2012/Published online: 23 December 2012

(C) The Author(s) 2012. This article is published with open access at Springerlink.com

\begin{abstract}
The concentration of heavy metals was studied in the soil samples collected around the municipal solid waste (MSW) open dumpsite, Ariyamangalam, Tiruchirappalli, Tamilnadu to understand the heavy metal contamination due to leachate migration from an open dumping site. The dump site receives approximately 400-470 tonnes of municipal solid waste. Solid waste characterization was carried out for the fresh and old municipal solid waste to know the basic composition of solid waste which is dumped in the dumping site. The heavy metal concentration in the municipal solid waste fine fraction and soil samples were analyzed. The heavy metal concentration in the collected soil sample was found in the following order: $\mathrm{Mn}>\mathrm{Pb}>\mathrm{Cu}>\mathrm{Cd}$. The presence of heavy metals in soil sample indicates that there is appreciable contamination of the soil by leachate migration from an open dumping site. However, these pollutants species will continuously migrated and attenuated through the soil strata and after certain period of time they might contaminate the groundwater system if there is no action to be taken to prevent this phenomenon.
\end{abstract}

Keywords Heavy metal - Municipal solid waste . Leachate - Open dumpsite

\section{Introduction}

Rapid industrialization and population explosion in India has led to the migration of people from villages to cities,

S. Kanmani · R. Gandhimathi $(\square)$

Department of Civil Engineering, National Institute

of Technology, Tiruchirappalli, Tamilnadu, India

e-mail: rgmathii@nitt.edu which generate thousands of tonnes of MSW daily. The amount of MSW is expected to increase significantly in the near future as the country strives to attain an industrialized nation status by the year 2020 [Sharma and Shah 2005; Central Pollution Control Board (CPCB) 2004; Shekdar et al. 1992]. Solid wastes are the organic and inorganic wastes generated by rapidly increasing production, consumption and other human and animal activities of the urban society, normally discarded as useless or unwanted or those that have lost their value to the first user and are a major cause of pollution (Berkun 1991; Mee and Topping 1998). Solid waste composition varies substantially with socio-economic conditions, location, season, waste collection and disposal methods, sampling and sorting procedures and many others factors (El-Fadel et al. 1997). The increasing amounts of municipal solid waste generated each year in several industrialized countries have raised concerns about the economic viability and environmental acceptability of the current waste-disposal methodologies (Daskalopoulos et al. 1998). The ever-increasing consumption of resources results in huge amounts of solid wastes from industrial and domestic activities, which pose significant threats to human health (Ziadat and Mott 2005). Although developed countries have established regulatory programmes for the disposal of solid wastes, developing countries have generally continued to use unsophisticated methods such as open dumps (Kocasoy 2002). Open dumps - unfortunately are still the means of disposal of solid wastes in developing countries-where the waste is dumped in uncontrolled manner, can be detrimental to the urban environment. Provisions for leachate and gas control system do not exist. A soil cover is rarely provided, except at the time of closure of the site. Most of the disposal sites are unfenced and open firing of municipal solid waste is very common. It putrefies easily under the hot tropical 
temperatures and generates considerable quantities of leachates and obnoxious odor (Everett 1992; Knoll 1983; Adhikari et al. 2006; Amoah et al. 2007). Under such circumstances, organic waste may also act as an important breeding site for disease causing vermin including flies, insects and rodents, which are vectors of diseases such as cholera, diarrhea, dysentery and typhoid fever (Fobil et al. 2008; Everett 1992; Knoll 1983; Afrane et al. 2004; Krajewski et al. 2001; Musmeci and Gucci 1997).

Solid waste disposals (open dumps, landfills, sanitary landfills or incinerators) represent a significant source of metals released into the environment (Yarlagadda et al. 1995; Waheed et al. 2010; Iwegbue et al. 2010; Bretzel and Calderisi 2011; Rizo et al. 2012). Leachate is produced primarily in association with precipitation that infiltrates through the refuse and normally results in the migration of leachate into the groundwater zone and pollutes it (Samuding 2009). Due to migration of leachate, soils have been contaminated with heavy metals such as lead, copper, zinc, iron, manganese, chromium, and cadmium and these heavy metals in solid wastes lead to serious problems because they cannot be biodegraded (Hong et al. 2002). The major sources of heavy metals in landfills are the co-disposed industrial wastes, incinerator ashes, mine wastes and household hazardous substances such as batteries, paints, dyes, inks, etc. (Erses and Onay 2003). Soil contamination by heavy metals from waste disposal sites is a serious problem in industrial and urban areas (Mandal and Sengupta 2006). Soils are regarded as the ultimate sink for heavy metals discharged into the environment, as many heavy metals are bound to soils (Obiajunwa et al. 2002). Furthermore, when screening for pollutants in soil and leachate at contaminated sites, the results are often required directly, since classification of the soil is needed before determination of remediation techniques (Banar et al. 2007). Hence, this study has been carried out to assess the soil contamination around the local dump area where the municipal solid wastes have been disposed for about 45 years.

This study was conducted on the samples collected from the Ariyamangalam municipal solid waste open dump site. The present study examines basic composition of the waste in the open dumpsite, then the assessment of heavy metal contamination and its concentration level in solid waste. The concentration of heavy metals was determined in the runoff leachate and its potential to the soil nearby the dumpsite area was also investigated.

Description of the study area

Tiruchirappalli better called as Trichy, situated on the banks of the river Cauvery is the fourth largest municipal corporation in Tamil Nadu and also the fourth largest urban agglomeration in the state. The district has an approximate population of 27 lakhs and the population density of 602 inhabitants per square kilometer. Many industries like steel, automobiles, distilleries, small scale industries and boiler manufacturing industries have crop up within a few decades of time. The maximum temperature experienced in this district is $37.7^{\circ}$ and the minimum temperature is $18.9^{\circ}$. The normal annual rainfall is $842.60 \mathrm{~mm}$. The estimated MSW generation in Trichy district is about 400-600 tonnes per day. The district is served by an open dumping yard namely Ariyamangalam garbage ground located $12 \mathrm{~km}$ from the city which is in Trichy-Thanjavur highway. The dumping site is located at $10^{\circ} 48^{\prime} \mathrm{N}$ and $78^{\circ} 43^{\prime} \mathrm{E}$. The ground elevation of the dumping site is $75.875 \mathrm{~m}$ above mean sea level. The Ariyamangalam dumping site has been in operation since 1967 , covering a total surface area of 47.7 acres where the geological formation is consisting of mainly alluvium (based on the data collected from Public Works Department, Tamilnadu). The nature of soil in the dumping site is of partially and highly weathered granitic gneiss type, the granites are yellow and reddish in color, hard massive to foliated and well-jointed. The soil is moderately permeable and the infiltration rate can absorb most of the rain except for more intensive rains which can cause considerable surface flow and erosion. The layout of the study area is shown in Fig. 1a. The Tiruchirappalli municipal corporation consists of four zones namely Srirangam, Ponmalai, Ariyamangalam and Abishegapuram. The dump site receives approximately 400-470 tonnes of MSW per day collected from four zones. The height of dump is around $3-4 \mathrm{~m}$ above ground level. In this dump yard, waste is disposed without segregation and compaction. No daily or intermediate cover is placed over the deposited waste. There is no lining at the bottom of the dump yard. Access to the site is freely available to all and the site is regularly utilized by rag pickers, scavenging for recyclable materials, and by a variety of animals, including water buffalo, cattle, pigs, and dogs, scavenging for food waste. Figure $1 \mathrm{~b}$ shows the present condition of the dumping site.

\section{Materials and methods}

Chemicals and reagents

All the chemicals used in this study were of analytical reagent (AR) grade and were supplied by Ranbaxy chemicals Ltd., Chennai, India. Glassware used for analysis was washed with acid solution followed by distilled water. 
Fig. 1 a Study area with sampling locations ( solid waste, $\$$ leachate and $\$$ soil sampling locations),

b photographical view of the Ariyamangalam open dumping site (a)

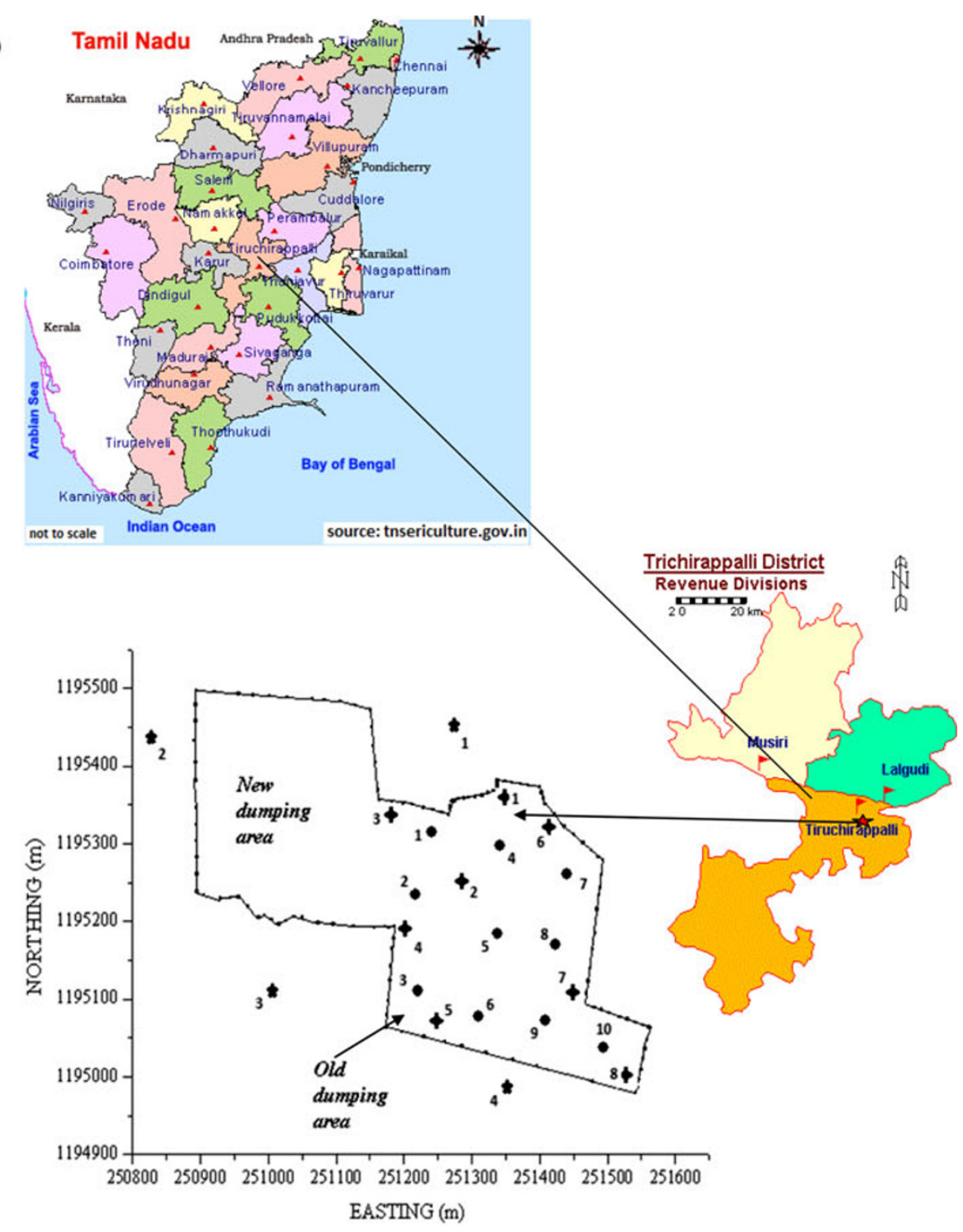

(b)

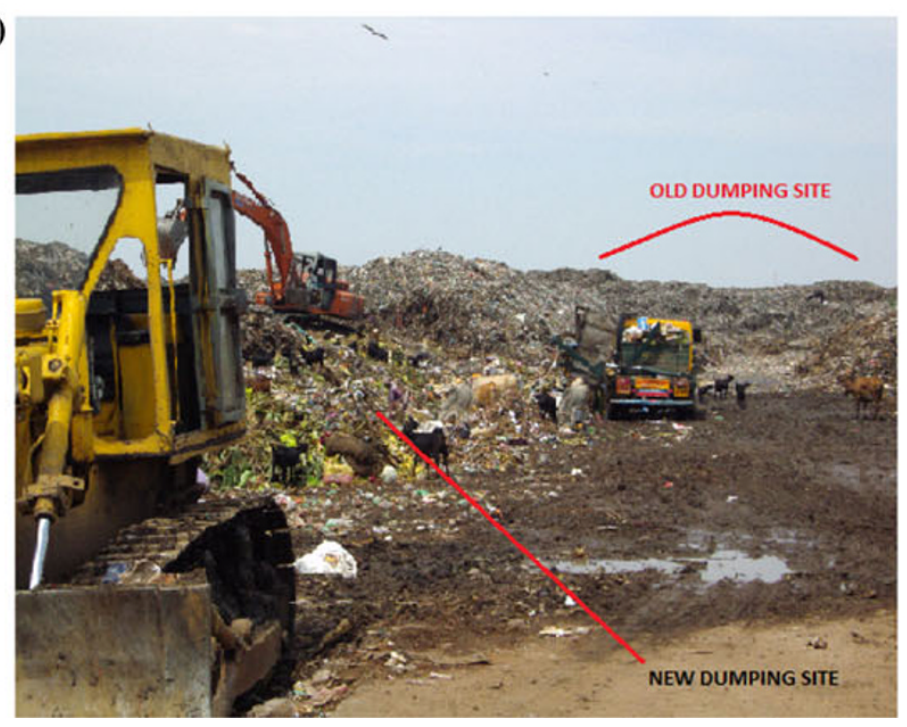


Solid waste sampling and characterization

For characterizing fresh municipal solid waste, study can be carried out either by collecting samples from curbside or from garbage trucks arriving at a landfill (Bagchi 2004). To assess the fresh solid waste composition, a total of 60 fresh solid waste samples (three samples from each zone per day) from the four different zones of Trichy city were collected for 5 days from the truck discharge point to the dumping site. For composition of municipal solid waste in the old dumping area (greater than 3 years), samples were collected using auger boring. For representative sample collection, the entire old dumping area was divided into number of grids and boreholes were drilled with a $15-\mathrm{cm}$ manual auger up to $3 \mathrm{~m}$. Solid waste samples were collected at every $1.5 \mathrm{~m}$ interval (top surface, $1.5 \mathrm{~m}$ and $3 \mathrm{~m}$ depth from top surface). Samples were properly labeled and brought to the laboratory for analysis. A total of 30 samples were collected from the dumping site from ten locations. The solid waste sampling locations in old dumping area are also shown in Fig. 1. The collected fresh solid waste and waste from old dumping area were segregated into different categories viz. paper, plastics, metals, glass, debris, vegetables, textiles, etc. The segregated samples were weighed individually. The mean of the solid waste composition was calculated using the results of the composition of each of the sorting samples (Gidarakos et al. 2005). The solid waste was characterized with regard to its constitutive moisture content by oven drying (at $105^{\circ} \mathrm{C}$ during $24 \mathrm{~h}$ ). The moisture content was expressed as the ratio of the mass of constitutive water to the mass of solid particles (Laurent et al. 2005).

\section{Leachate sampling and analysis}

The leachate corresponds to rainwater that has percolated through waste, interacting with bacteriological activity and especially organic substances. Its composition is a function of the nature and the age of the landfill, the type of wastes, the method of burying, the geological nature of the site and the climate (Amina et al. 2004). To study the physicochemical composition of leachate, the leachate samples were collected from actual leachate streams in the solid waste dumping site using $5 \mathrm{~L}$ polypropylene carboys that were rinsed out thrice prior to sample collection using distilled water and transported to the laboratory, stored at $4{ }^{\circ} \mathrm{C}$ and analyzed within 2 days. A total of eight leachate samples (L1 to L8) were collected for monitoring purpose. The physicochemical parameters such as $\mathrm{pH}$, biochemical oxygen demand (BOD), chemical oxygen demand (COD), total hardness, total dissolved solids, major cations such as $\mathrm{Ca}^{2+}, \mathrm{Mg}^{2+}$, and iron, major anion such as $\mathrm{Cl}^{-}$were determined. All the analyses in this study were repeated two or three times until concomitant values were obtained, and all the tests were carried out according to the standard methods (APHA 1998). The leachate sampling locations are also shown in Fig. 1a.

Soil sampling and analysis

Leachate causes the pollution of the soil, surface water and groundwater. The soil which is an important component of landfill site is a media where polluted materials are deposited. Because of continuous transportation to other media (air, ground and surface water) from this media by evaporation, erosion and infiltration, this component is a natural source which is needed to carefully monitor (Banar et al. 2009). In this content, soil characterization (organic matter, moisture content of the soil and $\mathrm{pH}$ of the soil, etc.) is very important on the amount and distribution of pollution (Taoeli 2007; El-Fadel et al. 1997; Daskalopoulos et al. 1997; Tchobanoglous et al. 1993). In the present study, the soil samples were collected from four locations (BH 1 to $\mathrm{BH} 4$ ) with the distance of $200 \mathrm{~m}$ from the Ariyamangalam open dump site boundary. Soil samples were collected at every $1.5 \mathrm{~m}$ interval (top surface, $1.5 \mathrm{~m}$ and $3 \mathrm{~m}$ depth from top surface) using auger boring. A total number of 12 samples (three samples at each depth from each location) were collected, properly labeled and brought to the laboratory for analysis. The soil sampling locations are also shown in Fig. 1a. All soil samples were air dried to a constant weight, sieved to $<2 \mathrm{~mm}$ through a stainless steel sieve and homogenized preserved in clean plastic containers for subsequent use (Chrastny et al. 2012). An index property such as specific gravity, moisture content and organic matter of the soil was determined according to IS codes. Water extracts were prepared based on modified standard test method for shake extraction of soil with water (ASTM 2006). Ten grams of soil was mixed with $100 \mathrm{ml}$ of distilled water (10:1 liquid to solid ratio) and shaked in a mechanical shaker for $18 \mathrm{~h}$. After the completion of the agitation, the surface water was removed by decantation followed by pressure filtration or centrifugation (good water recovery is essential) and preserved at $4{ }^{\circ} \mathrm{C}$ for later analysis. The water extracts were analyzed for the parameters such as $\mathrm{pH}$, electrical conductivity, chlorides, total alkalinity, total hardness, and iron.

Assessment of heavy metal contamination

Unorganized dumping of solid waste is predominant in developing countries like India and cause adverse impacts to the environment. Sources such as electronic goods, electro plating waste, painting waste, used batteries, etc., when dumped with municipal solid wastes increase the 
heavy metals in dumpsites. Slow leaching of these heavy metals under acidic environment during the degradation process leads to leachates with high metal concentrations. Since leachates are one of the potential sources of groundwater pollution, monitoring heavy metal content in dumpsite can facilitate to recommend suitable remedial measures (Esakku et al. 2003).

\section{Standards}

Standard solutions of heavy metals viz. copper $(\mathrm{Cu})$, cadmium $(\mathrm{Cd})$, manganese $(\mathrm{Mn})$ and lead $(\mathrm{Pb})$ were prepared using copper sulfate $\left(\mathrm{CuSO}_{4} .5 \mathrm{H}_{2} \mathrm{O}\right)$, cadmium sulfate $\left(\mathrm{CdSO}_{4} .8 \mathrm{H}_{2} \mathrm{O}\right)$, manganese sulfate $\left(\mathrm{MnSO}_{4} \cdot 7 \mathrm{H}_{2} \mathrm{O}\right)$ and lead nitrate $\left[\mathrm{Pb}\left(\mathrm{NO}_{3}\right)_{2}\right]$ were prepared using distilled water having 1,000 ppm concentration. Working standards were freshly prepared from the stock solutions.

\section{Instruments}

The heavy metal concentration present in the solid waste, leachate and soil was analyzed using atomic absorption spectrophotometer (AAS) supplied by Thermo Fisher Scientific, USA with D2 background correction lamp. Acetylene-air flame was used for higher concentrations ( $\mathrm{mg} / \mathrm{l})$.

\section{Sample preparation}

For heavy metal contaminant evaluation such as $\mathrm{Cd}, \mathrm{Cu}$, $\mathrm{Mn}$, and $\mathrm{Pb}$ on solid waste and soil, the collected 30 number of old solid waste samples and 12 number of bore hole soil samples were air dried, then grinded, screened through a $<2.360-\mathrm{mm}$ sieve and subjected to acid digestion. Acid digests of solid waste and soil samples were prepared as per the procedure postulated by (NEPM 1999). For the determination of total metal content, boiling aqua regia (3:1 hydrochloric/nitric acid) was used to extract the metals from the samples. The strong and concentrated acid mixture is capable of extracting inorganic metals. One gram of MSW fine fraction/soil was mixed with $18 \mathrm{ml}$ of concentrated $\mathrm{HCl}$ and $6 \mathrm{ml}$ of concentrated $\mathrm{HNO}_{3}$ and moistened with a little deionised water. The mixture was gently boiled in a hot plate until about $5-10 \mathrm{ml}$ of extract remains in the flask and allowed to cool for about $15 \mathrm{~min}$. Then, $18 \mathrm{ml}$ of concentrated $\mathrm{HCl}$ and $6 \mathrm{ml}$ of concentrated $\mathrm{HNO}_{3}$ were added and boiling was repeated till about $5-10 \mathrm{ml}$ of extract remains in the flask. After cooling, the extract was filtered through Whatman No. 42 filter paper and was made up to $50 \mathrm{ml}$ with distilled water. The heavy metal concentration present in the solid waste and soil samples were calculated using the following relation.
$M=\frac{(C-B) 50}{W}$

where,

$M=$ concentration of metal in the solid waste/soil, air dried basis $(\mathrm{mg} / \mathrm{kg})$,

$C=$ concentration of metal in the digest $(\mathrm{mg} / \mathrm{l})$,

$B=$ concentration of metal in the blank $(\mathrm{mg} / \mathrm{l})$,

$W=$ weight of air dried solid waste and soil sample digested $(\mathrm{g})$.

To analyze the heavy metal concentration in leachate, the collected eight leachate samples from the dumping area were filtered and preserved for soluble heavy metal analysis with a drop of concentrated nitric acid. The heavy metal analysis such as $\mathrm{Cd}, \mathrm{Cu}, \mathrm{Mn}$ and $\mathrm{Pb}$ were determined for the preserved leachate samples.

\section{Results and discussion}

Solid waste characterization

The yearly variation of MSW (disposed quantity) in Trichy city is shown in Fig. 2. The data on the solid waste generation in Trichy city were collected from Trichy Municipal Corporation. From Fig. 2, it was observed that the MSW generation rate for the Ariyamangalam dumping site varies between 115,845 and 149,100 tonnes/year for the year 2000-2010. This is largely because of rapid population growth, economic development in the country and increased consumption of packaged foods and other items. An average of 470 tonnes of domestic waste per day has been disposed on the active open dumpsite from the surroundings (based on the data collected from Trichy Municipal Corporation).

The mean of the fresh waste composition for the different zones within the Trichy Corporation was compared

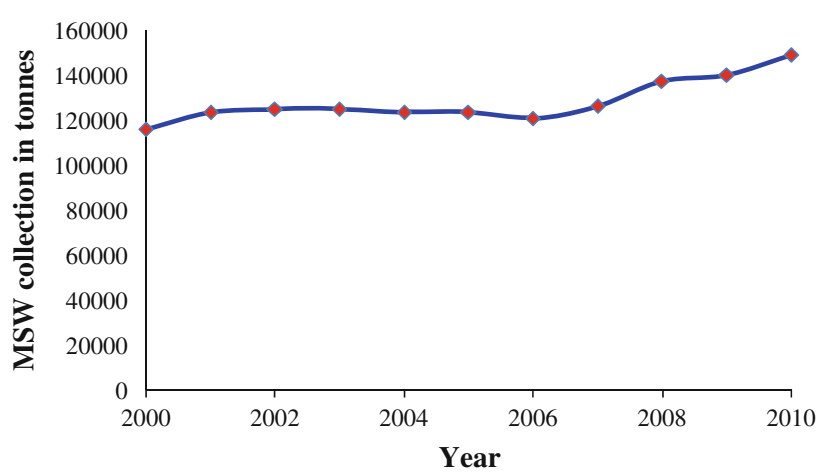

Fig. 2 Municipal solid waste generation (source: municipal corporation, Trichy city) 
Fig. 3 Fresh solid waste composition

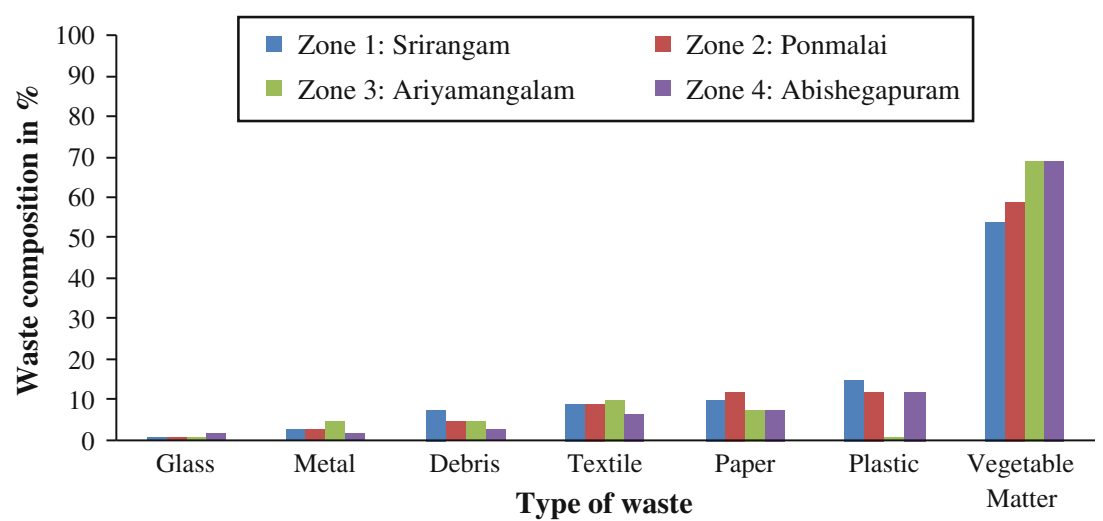

and is shown in Fig. 3. From Fig. 3, it was observed that the percentage of paper, textiles, plastic, debris, metals, glass, and vegetable waste are in the ranges of 8-10, 7-10, $1-15,3-8,2-5,1-2$, and 54-69\%, respectively. Vegetable waste is relatively high (54-69\%), as vegetable and meat wastes from market are transported to this open dumping site without any segregation for reuse. The share of glass (1-2\%) is considerable, mainly consisting of disposable (not refillable) bottles. The result from the fresh solid waste composition study shows that samples from the open dump site contained about 90-95\% combustible materials such as paper, textile, debris, plastic wastes. The non-combustible fraction such as metals and glass is about 1-5\%. The results were compared with solid waste composition reported by other researchers. Mohan and Gandhimathi (2009) reported that the MSW composition from Perungudi dumping site (Chennai City, Tamil Nadu) contained about
60-70\% combustible materials such as textile, leaves, plastics, food waste, etc., with an average of $65 \%$. The non-combustible fraction such as metals and glass was about $30-40 \%$ with an average of $35 \%$. The solid waste composition in most Asian countries is highly biodegradable, mainly composed of an organic fraction with high moisture content (Visvanathan et al. 2004). Kurian et al. (2012) revealed that the biodegradable waste was high when compared to non-biodegradable waste in MSW composition at Chennai city. The findings from other studies indicated that the composition of MSW is sitespecific and based on nature of waste and source location.

The composition of solid waste from old dumping area (Fig. 4) shows a significant variation at all depths and locations. It was observed that the dead leaves and wood chips and soil were 40-60 and 15-40\%, respectively. The plastic and paper composition was $8-15$ and $0.5-15 \%$,
Fig. 4 Solid waste composition from old dumping area

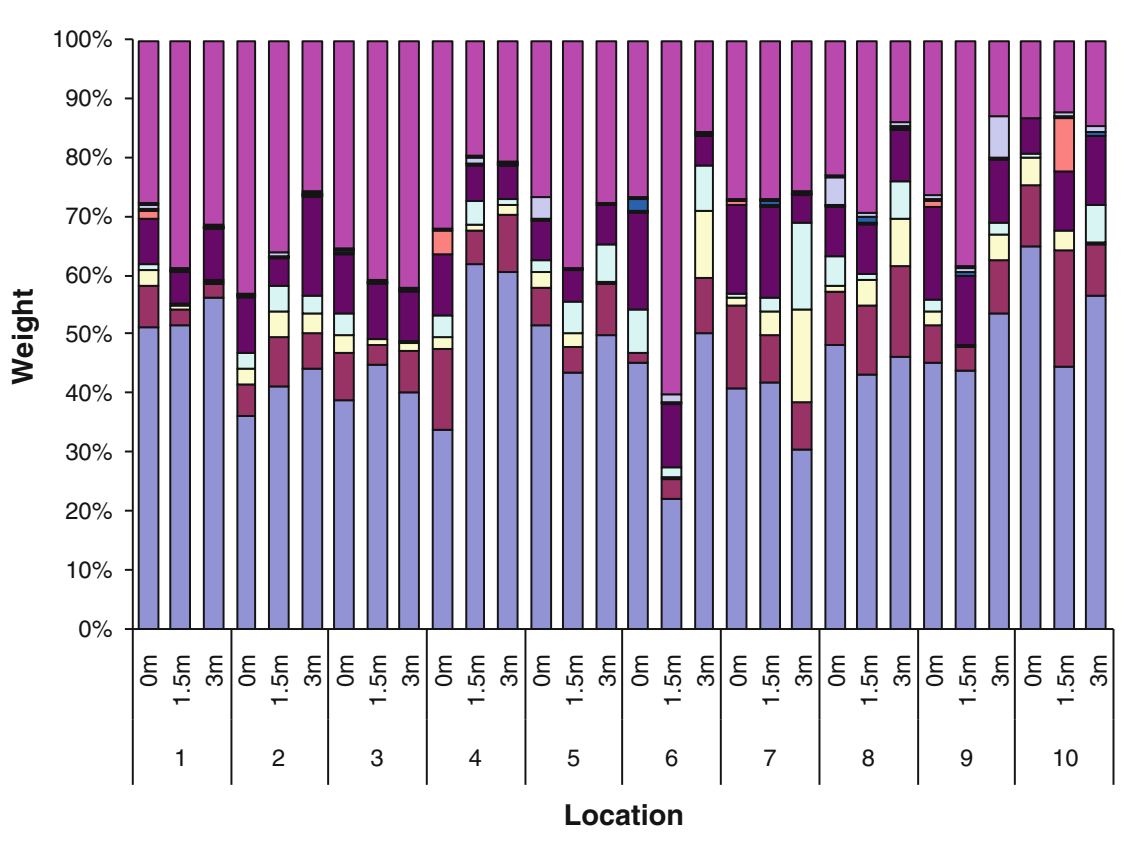

口Dead leaves \& Woodchips घPlastic $\square$ Paper $\square$ Textile घebrish $\square$ Rubber $\square$ Metal $\square$ Glass $\square$ Leather $\square$ Soil 
Table 1 Moisture content of municipal solid waste

\begin{tabular}{llllll}
\hline Zones & \multicolumn{2}{l}{ Moisture content $(\%)$} & & \\
\cline { 2 - 5 } & Day 1 & Day 2 & Day 3 & Day 4 & Day 5 \\
\hline Zone 1 & 9.65 & 13.32 & 11.24 & 15.4 & 16.2 \\
Zone 2 & 13.65 & 17.23 & 15.45 & 17.3 & 18.34 \\
Zone 3 & 21.45 & 27.45 & 25.67 & 29.31 & 27.5 \\
Zone 4 & 19.34 & 22.2 & 25.54 & 24.32 & 22.7 \\
\hline
\end{tabular}

Table 2 Physicochemical characteristics of leachate

\begin{tabular}{|c|c|c|c|c|c|c|c|c|c|c|c|c|}
\hline $\begin{array}{l}\text { Sample } \\
\text { no. }\end{array}$ & $\mathrm{pH}$ & $\begin{array}{l}\text { EC } \\
(\mu \mathrm{mho} / \mathrm{cm})\end{array}$ & $\begin{array}{l}\text { TDS } \\
(\mathrm{mg} / \mathrm{l})\end{array}$ & $\begin{array}{l}\text { Chlorides } \\
(\mathrm{mg} / \mathrm{l})\end{array}$ & $\begin{array}{l}\text { Total hardness } \\
\text { as } \mathrm{CaCO}_{3}(\mathrm{mg} / \mathrm{l})\end{array}$ & $\begin{array}{l}\mathrm{Ca}^{2+} \\
(\mathrm{mg} / \mathrm{l})\end{array}$ & $\begin{array}{l}\mathrm{Mg}^{2+} \\
(\mathrm{mg} / \mathrm{l})\end{array}$ & $\begin{array}{l}\text { Total alkalinity } \\
\text { as } \mathrm{CaCO}_{3}(\mathrm{mg} / \mathrm{l})\end{array}$ & $\begin{array}{l}\mathrm{BOD}_{5,20}^{\circ} \\
(\mathrm{mg} / \mathrm{l})\end{array}$ & $\begin{array}{l}\text { COD } \\
(\mathrm{mg} / \mathrm{l})\end{array}$ & $\begin{array}{l}\mathrm{BOD}_{5} / \\
\mathrm{COD}\end{array}$ & $\begin{array}{l}\text { Iron } \\
(\mathrm{mg} / \mathrm{l})\end{array}$ \\
\hline 1 & 7.55 & 32,940 & 22,070 & 1,999 & 8,000 & 1,280 & 1,152 & 6,000 & 1,050 & 26,880 & 0.04 & BDL \\
\hline 2 & 7.5 & 45,350 & 34,920 & $6,498.5$ & 9,500 & 1,920 & 1,128 & 12,000 & 1,100 & 27,840 & 0.04 & BDL \\
\hline 3 & 8.27 & 36,150 & 27,840 & $6,997.5$ & 7,000 & 1,680 & 672 & 10,500 & 1,575 & 31,680 & 0.05 & 1.28 \\
\hline 4 & 7.8 & 39,380 & 29,540 & 5,998 & 8,500 & 2,120 & 768 & 10,000 & 3,750 & 45,120 & 0.08 & 2.44 \\
\hline 5 & 8.47 & 28,710 & 21,250 & $3,996.5$ & 5,000 & 1,280 & 432 & 8,000 & 1,575 & 32,640 & 0.05 & 3.26 \\
\hline 6 & 7.84 & 39,540 & 30,450 & 5,996 & 8,750 & 2,268 & 739.2 & 9,500 & $1,912.5$ & 38,400 & 0.05 & 6.28 \\
\hline 7 & 7.28 & 23,850 & 16,460 & 1,996 & 5,200 & 1,548 & 319.2 & 7,000 & 3,450 & 37,440 & 0.09 & 6.01 \\
\hline 8 & 7.89 & 22,100 & 16,360 & 1,997 & 4,000 & 1,068 & 319.2 & 7,000 & 1,650 & 41,280 & 0.04 & 8.51 \\
\hline
\end{tabular}

respectively. Debris waste composition was 5-18\%. Leather, glass, rubber, and metal composition was relatively less when compared to other type of wastes. From the composition results it was found that the combustible waste composition was high when compared to non-combustible wastes.

The moisture content of fresh municipal solid waste was analyzed as per IS code and the results are given in Table 1. The moisture content varied from $9.65-29.31 \%$. From Table 1, it was found that the waste from zone three have very high moisture content compared to other zones. This is due to the disposal of huge quantity of vegetable wastes from the market.

\section{Leachate characteristics}

The significant variation of leachate quality among the collection locations is presented in Table 2. Table 2 shows the wide variation in the concentration of leachate parameters within the dumping site. This is mainly due to the nature of solid waste dumped in that particular location. It can be observed that the leachate sample possesses very high concentration of chemical parameters except $\mathrm{pH}$. All the collected leachate samples were amber-colored and alkaline with $\mathrm{pH}$ range of 7.28-8.47. This may be attributed to the decrease in the concentration of free volatile acids due to anaerobic decomposition, as fatty acids can be partially ionized and contribute to higher $\mathrm{pH}$ values. Alkaline $\mathrm{pH}$ is normally encountered at landfills, 10 years after disposal (El-Fadel et al. 2002). Since the $\mathrm{pH}$ of every sample was observed below 8.3 except one sample, the alkalinity of each sample might have been due to bicarbonate; a large amount of mineral species are also expected to exist in the leachate as the bicarbonate form (Seo et al. 2007). The relatively high value of electrical conductivity $(45,350 \mu \mathrm{mho} / \mathrm{cm})$ indicates the presence of dissolved inorganic materials in the samples. The concentration of TDS also fluctuates widely from 16,360 to $34,920 \mathrm{mg} / \mathrm{l}$. The range of COD varies from 26,880 to $45,120 \mathrm{mg} / \mathrm{l}$ and the BOD ranges between 1,050 and $3,750 \mathrm{mg} / \mathrm{l}$. It is commonly known that organics in leachate are characterized by different biodegradability. A measure of biodegradability is $\mathrm{BOD}_{5} / \mathrm{COD}$ ratio (Kulikowska and Klimiuk 2008). The $\mathrm{BOD}_{5} / \mathrm{COD}$ ratio (0.04 to 0.09 ) less than 0.1 indicate that the solid waste reached the methanogenic phase. The determined chloride concentration varies between 1,996 and $6,997.5 \mathrm{mg} / \mathrm{l}$. Chloride is a non-degradable conservative parameter and the change in its concentration is commonly used to assess the variation of leachate dilution (Bilgili et al. 2007). The results with relatively high $\mathrm{pH}$, alkalinity, and chloride concentration in all the leachate samples analyzed confirm the methanogenic condition of the dumpsite. The range of calcium and magnesium parameters is on the higher side $(1,068-2,268 \mathrm{mg} / \mathrm{l}$; $319.2-1,152 \mathrm{mg} / \mathrm{l})$. The presence of magnesium in the leachate is due to the disposal of construction waste along with MSW (Al-Yaqout and Hamoda 2003). The iron (Fe) concentration varies ranging from 1.28 to $8.51 \mathrm{mg} / \mathrm{l}$, except 
Table 3 Index properties of soil

Table 4 Physicochemical characteristics of soil

\begin{tabular}{llll}
\hline Sample details & \multicolumn{2}{l}{ Index properties } \\
\cline { 2 - 4 } & Organic content $(\%)$ & Moisture content $(\%)$ & Specific gravity \\
\hline BH: 1 (1 m from GL) & 4.49 & 3.35 & 2.28 \\
BH: 1 (2 m from GL) & 2.24 & 2.78 & 2.27 \\
BH: 1 (3 m from GL) & 2.59 & 3.06 & 2.26 \\
BH: 2 (1 m from GL) & 7.31 & 3.98 & 2.12 \\
BH: 2 (2 m from GL) & 1.96 & 0.65 & 2.33 \\
BH: 2 (3 m from GL) & 5.03 & 2.35 & 2.42 \\
BH: 3 (1 m from GL) & 4.35 & 4.11 & 2.22 \\
BH: 3 (2 m from GL) & 2.48 & 3.28 & 2.27 \\
BH: 3 (3 m from GL) & 1.73 & 3.69 & 2.32 \\
BH: 4 (1 m from GL) & 3.74 & 4.87 & 2.21 \\
BH: 4 (2 m from GL) & 3.17 & 3.1 & 2.25 \\
BH: 4 (3 m from GL) & 2.37 & 2.52 & 2.28 \\
\hline
\end{tabular}

\begin{tabular}{|c|c|c|c|c|c|c|}
\hline Sample details & $\mathrm{pH}$ & $\begin{array}{l}\text { Electrical } \\
\text { conductivity } \\
(\mu \mathrm{mho} / \mathrm{cm})\end{array}$ & $\begin{array}{l}\text { Chlorides } \\
(\mathrm{mg} / \mathrm{kg})\end{array}$ & $\begin{array}{l}\text { Total } \\
\text { alkalinity } \\
(\mathrm{mg} / \mathrm{kg})\end{array}$ & $\begin{array}{l}\text { Total } \\
\text { hardness } \\
(\mathrm{mg} / \mathrm{kg})\end{array}$ & $\begin{array}{l}\text { Iron } \\
(\mathrm{mg} / \mathrm{kg})\end{array}$ \\
\hline BH: 1 (1 m from GL) & 7.64 & 627 & 799 & 1,500 & 1,200 & 815.86 \\
\hline BH: 1 (2 $\mathrm{m}$ from GL) & 8.01 & 255 & 1,999 & 1,800 & 2,000 & 893.58 \\
\hline BH: 1 (3 m from GL) & 7.99 & 320 & 1,999 & 1,900 & 1,000 & 1027.55 \\
\hline BH: 2 (1 $\mathrm{m}$ from GL) & 7.55 & 124.8 & 2,999 & 1,000 & 1,800 & 893.73 \\
\hline BH: 2 (2 $\mathrm{m}$ from $\mathrm{GL})$ & 7.56 & 114.8 & 2,999 & 600 & 2,300 & 673.42 \\
\hline BH: 2 (3 m from $G L)$ & 7.55 & 134.3 & 199 & 1,200 & 3,300 & 808.55 \\
\hline $\mathrm{BH}: 3$ (1 $\mathrm{m}$ from $\mathrm{GL})$ & 7.56 & 326 & 599 & 900 & 2,600 & 837.70 \\
\hline BH: 3 (2 m from GL) & 7.8 & 281 & 599 & 1,000 & 2,700 & 617.28 \\
\hline BH: 3 (3 m from GL) & 7.66 & 266 & 499 & 1,000 & 2,500 & 571.65 \\
\hline BH: 4 (1 m from GL) & 7.71 & 290 & 799 & 600 & 3,600 & 807.7 \\
\hline BH: 4 (2 m from GL) & 7.31 & 196.3 & 6,998 & 6,000 & 13,000 & 713.73 \\
\hline $\mathrm{BH}: 4$ (3 m from GL) & 7.27 & 194.1 & 5,998 & 4,000 & 14,000 & 770.84 \\
\hline
\end{tabular}

the sample locations two and three. The Fe concentration in the leachate sample indicates that Fe and steel scrap are also dumped in the landfill. The dark brown color of the leachate is mainly attributed to the oxidation of ferrous to ferric form and the formation of ferric hydroxide colloids and complexes with fulvic/humic substance (Chu et al. 1994).

\section{Characteristics of soil}

The collected soil samples from the dumping site were analyzed for index properties and for various physicochemical parameters. The results are reported in Tables 3 and 4, respectively. From Table 3, it was observed that the organic content of the soil ranges from 1.73 to $7.31 \%$. The maximum organic content was observed at bore hole location two (BH 2). The moisture content of the soil samples ranged from 0.65 to $4.87 \%$ with lowest value of $0.65 \%$ corresponding to two soil sample locations one and two with $2 \mathrm{~m}$ below the ground level. The results indicated that the moisture content was high in the top layer $(1 \mathrm{~m}$ from the ground level) in all the locations. The specific gravity of soil ranges from 2.12 to 2.42 , and this value is very less when compared to sand, which is free from organic pollution.

From the physicochemical characteristics of the soil sample, it was observed that the $\mathrm{pH}$ value of the soil sample was alkaline in nature with the range from 7.27 to 8.01. The electrical conductivity of the soil sample ranges from 114.8 to $627 \mu \mathrm{mho} / \mathrm{cm}$. The range of parameters such as chlorides, total alkalinity and total hardness varies in the ranges of 199-6,998, 600-6,000, and 1,000-14,000 mg/kg, respectively. The presence of high value of $\mathrm{pH}$, alkalinity, chloride and iron concentration in the soil samples (BH: three and four) nearby dumping site suggested that the soil samples were contaminated by leachate migration from open dumping site. 
Fig. 5 Variation of manganese concentration in the solid waste samples

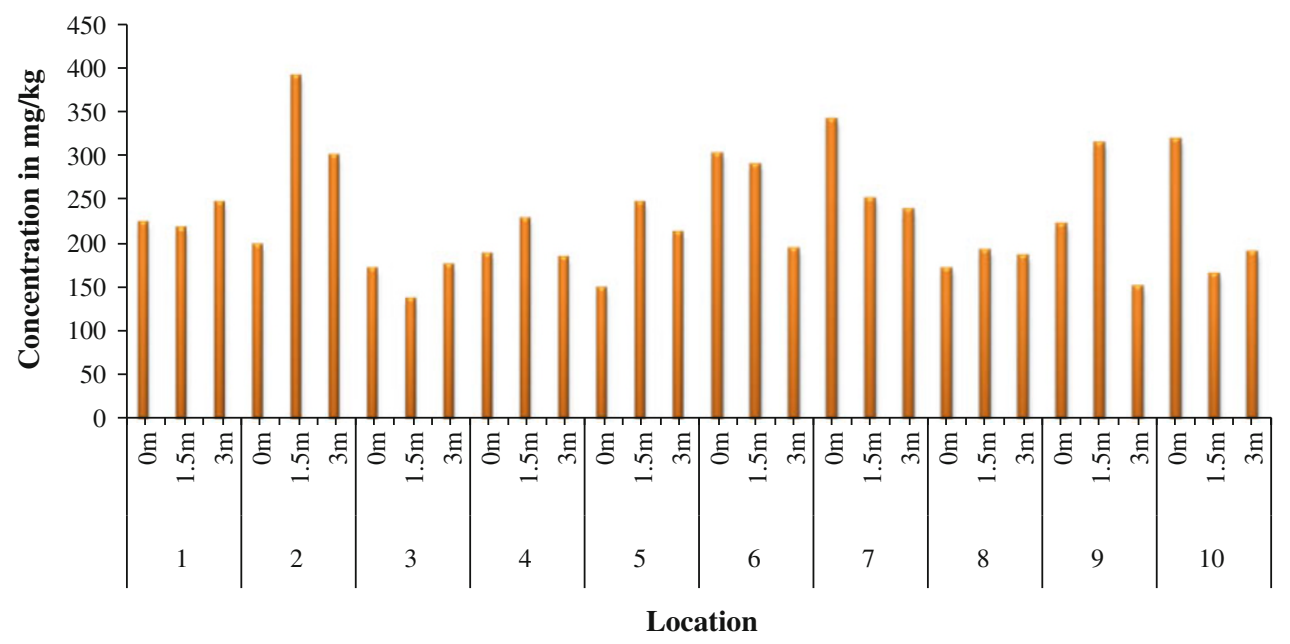

Fig. 6 Variation of copper concentration in the solid waste samples
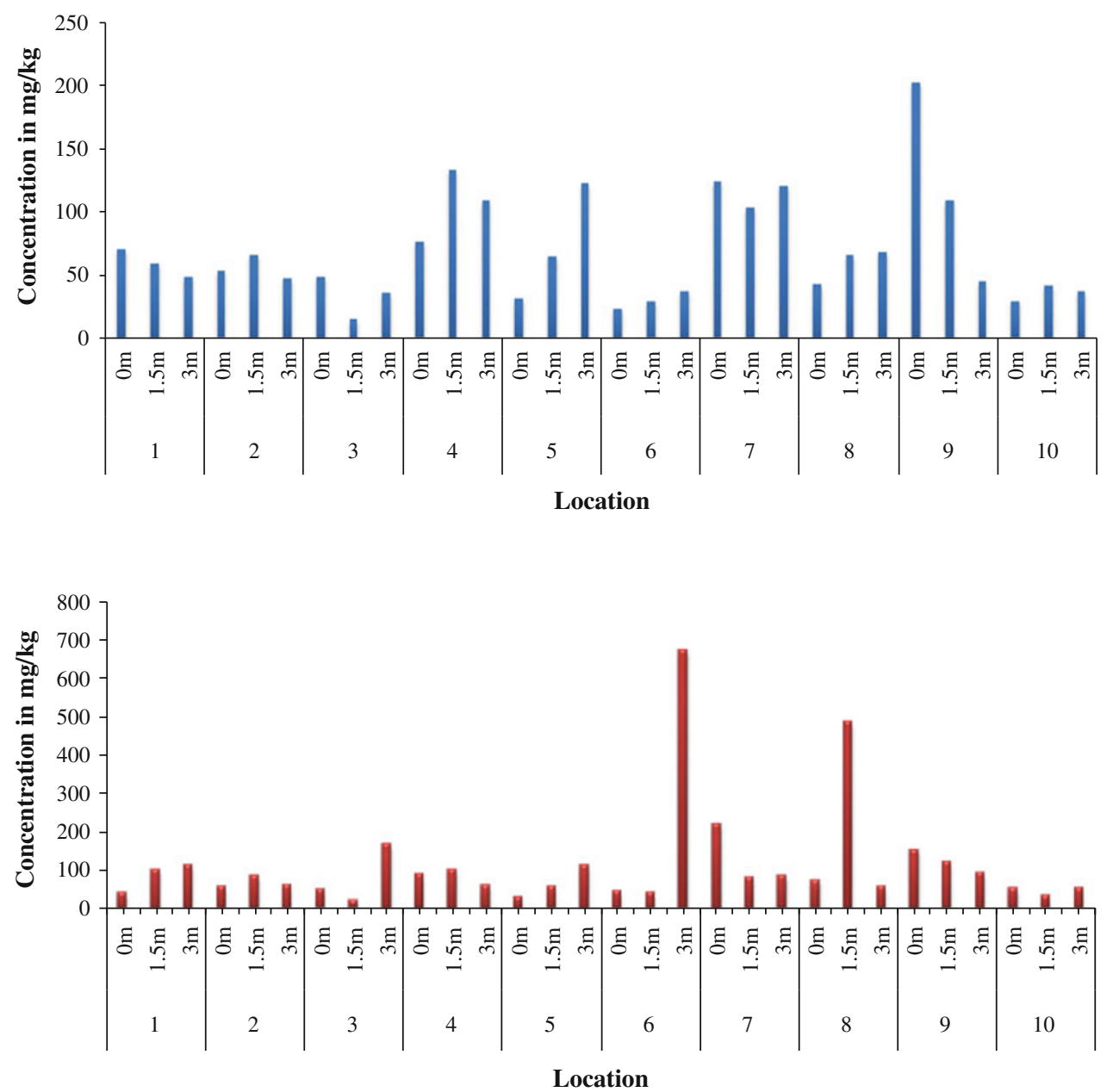

Fig. 7 Variation of lead concentration in the solid waste samples
Heavy metal assessment

\section{Solid waste}

Depth wise variation of heavy metal concentration $(\mathrm{mg} / \mathrm{kg})$ extracted from old solid waste samples by acid digestion method was shown in Figs. 5, 6, 7, and 8. It was observed that there was no significant difference in the heavy metal concentration between the sampling sites and depth interval. From Fig. 5, a very high concentration of Mn was noticed at all the locations and high concentration of $\mathrm{Cu}$ was found at SW4, SW5, SW7, and SW9 locations (Fig. 6). The sources of Manganese in the site are expected to be due to disposal of bottle caps, blades, and pharmaceuticals, 
Fig. 8 Variation of cadmium concentration in the solid waste samples

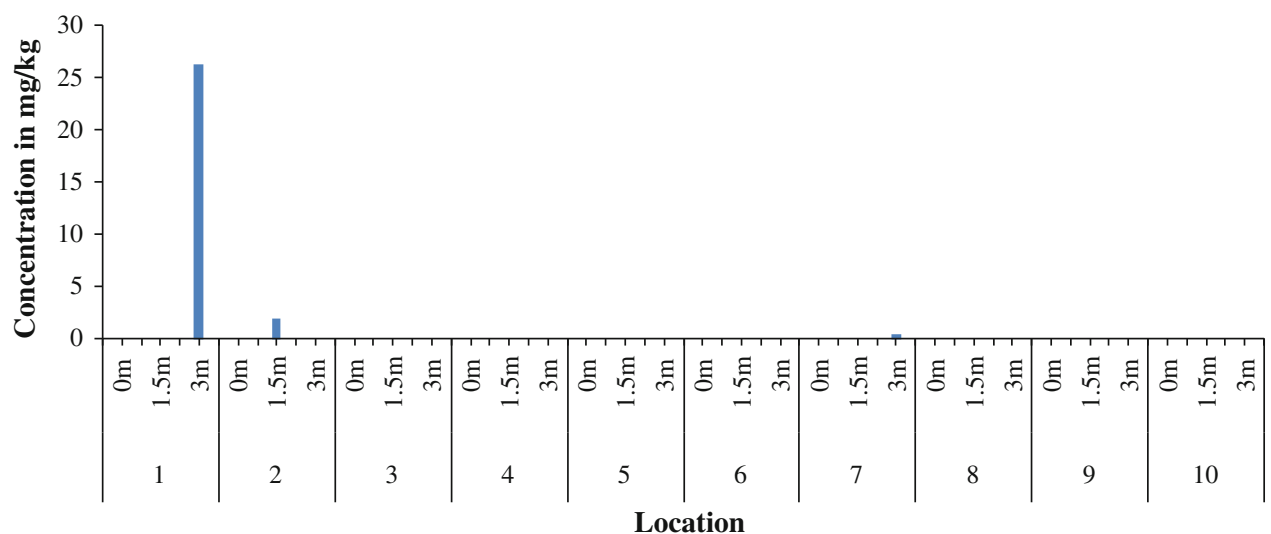

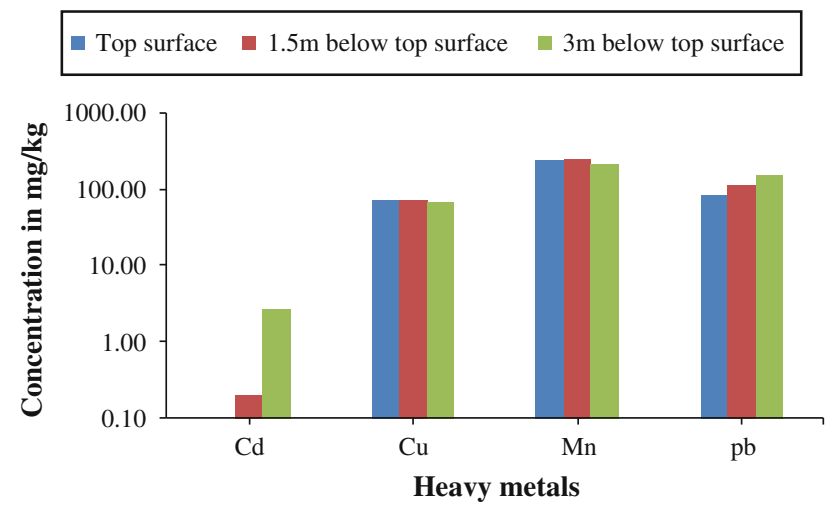

Fig. 9 Variation of heavy metal concentration in the solid waste samples

galvanizing, paints, pigments, insecticides and cosmetics along with garbage. The concentration of $\mathrm{Pb}$ was found to be high in locations SW6 and SW8 (Fig. 7). The high levels of $\mathrm{Pb}$ and $\mathrm{Cu}$ in these areas may have resulted from inclusions of chalcopyrite in battery and ore processed at the smelters (Germani et al. 1981). The cadmium concentration was high in location one at $3 \mathrm{~m}$ below top surface and BDL in other locations (Fig. 8). It was observed that the concentration of metals $(\mathrm{Cu}, \mathrm{Mn}$ and $\mathrm{Pb})$ was high in the middle layers ( $1.5 \mathrm{~m}$ below top surface) in all locations when compared to top surface and $3 \mathrm{~m}$ below the top surface. This may be due to the fact that over the time, the leachates have moved downward. Since the bottom layer was saturated with leachate, lower concentrations have been observed in this layer.

The average variation of heavy metal concentration in the old solid waste samples was shown in Fig. 9. Based on results of depth wise variation of heavy metal concentration, it is concluded that the heavy metal concentrations present in the solid waste samples depends on site conditions as well as conditions prevailing in the sampling locations. Based on the average concentration, the heavy metal concentration in the collected solid waste sample was found in the following order: $\mathrm{Mn}>\mathrm{Cu}>\mathrm{Pb}>\mathrm{Cd}$.

\section{Leachate}

Heavy metals are typically released by acidic $\mathrm{pH}$. Usually these heavy metals are found at moderate concentration levels in municipal landfill leachates (Jensen et al. 1999). From Table 5, it can be observed that $\mathrm{Cd}, \mathrm{Cu}, \mathrm{Mn}$ and $\mathrm{Pb}$ concentration values are in the ranges 0.1641-1.0372, $0.546-2.6886,0.1605-1.7962$, and $0.7655-5.1485 \mathrm{mg} / \mathrm{l}$, respectively, for the collected leachate samples. The high level of $\mathrm{Pb}(5.1485 \mathrm{mg} / \mathrm{l})$ in the leachate samples indicates the disposal of $\mathrm{Pb}$ batteries, chemicals for photograph processing, $\mathrm{Pb}$-based paints and pipes at the landfill site (Moturi et al. 2004; Mor et al. 2005). Based on the average concentration, the heavy metal concentration in the collected leachate sample was found in the following order: $\mathrm{Pb}>\mathrm{Mn}>\mathrm{Cu}>\mathrm{Cd}$.

\section{Soil}

Contamination of heavy metals in the environment is of major concern because of their toxicity and threat to human life and the environment (Purves 1985). Many investigators have conducted researches on heavy metal contamination in soils resulting from various anthropogenic sources such as industrial and municipal wastes (Haines and Pocock 1980; Parry et al. 1981; Culbard et al. 1983; Gibson and Farmer 1983; Olajire and Ayodele 1998). In this study, the concentrations of heavy metal present in the collected soil sample were reported in Table 6. Out of 12 soil samples, 5 samples were only observed with the $\mathrm{Cu}$ concentration. It is well known that copper is a rather immobile element in soils, and the greatest amounts of adsorbed copper have always found for $\mathrm{Fe}$ and $\mathrm{Mn}$ oxides (Kabata-Pendias and Pendias 2000). The concentration of $\mathrm{Cd}$ in the collected soil sample was observed very less, because the concentration of $\mathrm{Cd}$ in the solid waste and leachate was found to be very meager. The manganese concentrations were totally observed for all the 12 samples with the ranges between 420.7 and $1711.6 \mathrm{mg} / \mathrm{kg}$. Lead has highly chalcophilic 
Table 5 Concentrations of heavy metal for the collected leachate sample

** Detection limit of the analytical instrument

Table 6 Concentrations of heavy metal for the collected soil sample

\begin{tabular}{lllll}
\hline Sample no. & $\mathrm{Cd}(\mathrm{mg} / \mathrm{l})$ & $\mathrm{Cu}(\mathrm{mg} / \mathrm{l})$ & $\mathrm{Mn}(\mathrm{mg} / \mathrm{l})$ & $\mathrm{Pb}(\mathrm{mg} / \mathrm{l})$ \\
\hline L1 & BDL & BDL & BDL & BDL \\
L2 & BDL & BDL & BDL & BDL \\
L3 & BDL & 0.8527 & BDL & BDL \\
L4 & 0.1641 & 1.9182 & 0.1605 & 0.7655 \\
L5 & 0.351 & 1.1649 & 0.5534 & 1.7911 \\
L6 & 0.6034 & 2.6886 & 1.058 & 2.931 \\
L7 & 0.8312 & 1.5149 & 1.7893 & 4.1013 \\
L8 & 1.0372 & 0.546 & 1.7962 & 5.1485 \\
$* *$ & 0.0040 & 0.0150 & & 0.0300 \\
\hline
\end{tabular}

\begin{tabular}{lllll}
\hline Sample details & $\mathrm{Cu}(\mathrm{mg} / \mathrm{kg})$ & $\mathrm{Cd}(\mathrm{mg} / \mathrm{kg})$ & $\mathrm{Mn}(\mathrm{mg} / \mathrm{kg})$ & $\mathrm{Pb}(\mathrm{mg} / \mathrm{kg})$ \\
\hline BH: 1 (1 m from GL) & BDL & 43.63 & 151.70 & 44.09 \\
BH: 1 (2 m from GL) & BDL & BDL & 156.14 & 116.14 \\
BH: 1 (3 m from GL) & BDL & BDL & 140.52 & 173.62 \\
BH: 2 (1 m from GL) & 75.52 & 5.19 & 140.45 & 233.32 \\
BH: 2 (2 m from GL) & 34.31 & 10.01 & 117.48 & 291.29 \\
BH: 2 (3 m from GL) & 39.27 & 19.37 & 139.51 & BDL \\
BH: 3 $(1 \mathrm{~m}$ from GL) & 28.99 & 30.58 & 171.16 & BDL \\
BH: 3 (2 m from GL) & 4.53 & BDL & 42.07 & BDL \\
BH: 3 (3 m from GL) & BDL & BDL & 56.52 & BDL \\
BH: 4 (1 m from GL) & BDL & 38.41 & 151.45 & 73.27 \\
BH: 4 (2 m from GL) & BDL & 47.72 & 145.33 & 123.60 \\
BH: 4 (3 m from GL) & BDL & BDL & 151.32 & 178.84 \\
\hline
\end{tabular}

properties. Thus, its primary form in its natural state is galena $(\mathrm{PbS})$, and the natural lead content of soil is inherited from parent rocks (Kabata-Pendias and Pendias 2000; Son and Jung 2011). From Table 6, the concentration of lead was observed in the ranges from 44.09 to $178.84 \mathrm{mg} / \mathrm{kg}$. The distribution of metal among specific forms varies widely based on the metal's chemical properties and soil characteristics (Soon and Bates 1981; Olajire and Ayodele 1998). Based on the average concentration, the heavy metal concentration in the collected soil sample was found in the following order: $\mathrm{Mn}>\mathrm{Pb}>\mathrm{Cu}>\mathrm{Cd}$.

\section{Remedial measures}

From the physicochemical characteristics and heavy metal concentration present in the leachate and soil samples, it is claimed that Ariyamangalam open dumping site is going to cause environmental problems in both short and long term and this site should be renewed. Hence, the active dumping site should be closed by a proper control with liner provision. In the capped dumping site (landfill) there is a provision for leachate collection system and gas monitoring system (Allen 2001). The provision of liner in the landfill protects the surrounding environment including soil, groundwater and surface water by containing leachate generated within the landfill, controlling ingress of ground water and assisting in the control of the migration of landfill gas (Koerner and Soong 2000). Hence, the leachate migration through soil and obnoxious odor can be avoided. Integrated solid waste management system for this open dumping has to be time-honored and new sanitary landfill site has to be constructed (Banar et al. 2007, 2009). This resolution keeps away from groundwater contamination due to the disposal of municipal solid wastes.

\section{Conclusions}

The indiscriminate disposal of MSW without covering is considered a dangerous practice in integrated waste management at the global level. The fresh solid waste composition study shows that samples from the open dump site contained about 90-95\% combustible materials and noncombustible fraction is about $1-5 \%$. The composition of existing solid waste from old dumping area shows a significant variation at all depths and locations. It was observed that the dead leaves and wood chips and soil were 
40-60 and 15-40\%, respectively. The plastic and paper composition was $8-15$ and $0.5-15 \%$, respectively. Debris waste composition was 5-18\%. The physicochemical characteristic of leachate shows that the range of COD varies from 26,880 to $45,120 \mathrm{mg} / \mathrm{l}$ and the $\mathrm{BOD}_{5} / \mathrm{COD}$ ratio was less than 0.1 . Hence, the characterization of leachate confirms the methanogenic condition of the dumpsite. Based on the average concentration, the heavy metal components in the old solid waste, leachate and soil were found in the following orders: $\mathrm{Mn}>\mathrm{Cu}>\mathrm{Pb}>\mathrm{Cd}$; $\mathrm{Pb}>\mathrm{Mn}>\mathrm{Cu}>\mathrm{Cd} ; \mathrm{Mn}>\mathrm{Pb}>\mathrm{Cu}>\mathrm{Cd}$. The presence of heavy metals $(\mathrm{Pb}, \mathrm{Cu}, \mathrm{Mn}$, and $\mathrm{Cd})$ in soil sample indicates that there is appreciable contamination of the soil by leachate migration. This is indicated that the migration and distribution of the contaminants species are still localized and not diffused with a wide area. However, these pollutant species continuously migrate and percolate through the soil strata and after certain period of time might contaminate the groundwater system if no action is taken to prevent this phenomenon.

Acknowledgments We sincerely thank the Department of Science and Technology, New Delhi for the financial support rendered to carry out the research work. We also thank the Corporation of Tiruchirappalli for the permission to carry out the studies at the open dumpsites.

Open Access This article is distributed under the terms of the Creative Commons Attribution License which permits any use, distribution, and reproduction in any medium, provided the original author(s) and the source are credited.

\section{References}

Adhikari BK, Barrington S, Martinez J (2006) Predicted growth of world urban food waste and methane production. Waste Manag Res 24(5):21-33

Afrane YA, Klinkenberg E, Drechsel P, Owusu-Daaku K, Garms R, Kruppa T (2004) Does irrigated urban agriculture influence the transmission of malaria in the city of Kumasi Ghana? Acta Trop 89(2):125-134

Allen A (2001) Containment landfills: the myth of sustainability. Eng Geol 60:3-19

Al-Yaqout AF, Hamoda MF (2003) Evaluation of landfill leachate in arid climate-a case study. Environ Int 29:593-600

Amina C, Abdekader Y, Elkbri L, Jacky M, Alain V (2004) Environmental impact of an urban landfill on a costal aquifer (El Jadida Morocco). J Afr Earth Sci 39:509-516

Amoah P, Drechsel P, Henseler M, Abaidoo RC (2007) Irrigated urban vegetable production in Ghana: microbiological contamination in farms and markets and associated consumer risk groups. J Water Health 5(3):455-466

APHA (1998) Standard methods for the examination of water and wastewater, 17th edn. American Public Health Association, Washington

ASTM D3987 (2006) Standard test method for shake extraction of solid waste with water. Annual book of American Society for Testing and Materials standards
Bagchi A (2004) Design of landfills and integrated solid waste management. Wiley, New Jersey

Banar M, Ozkan A, Vardar CI (2007) Characterization of an urban landfill soil by using physicochemical analysis and solid phase microextraction (SPME) - GC/MS. Environ Monit Assess 127: $337-351$

Banar M, Ozkan A, Altan M (2009) Modelling of heavy metal pollution in an unregulated solid waste dumping site with GIS research. J Environ Earth Sci 1(2):99-110

Berkun M (1991) Solid waste characteristic and removal planning in the Eastern Black Sea. Region research projects no. 91112001 , Karadeniz Technical University, Trabzon, Turkey

Bilgili MS, Demir A, Bestamin O (2007) Influence of leachate recirculation on aerobic and anaerobic decomposition of solid wastes. J Hazard Mater 143:177-183

Bretzel FC, Calderisi M (2011) Contribution of a municipal solid waste incinerator to the trace metals in the surrounding soil. Environ Monit Assess 182:523-533

Central Pollution Control Board (CPCB) (2004) Management of municipal solid waste. Ministry of Environment and Forests, New Delhi, India

Chrastny V, Vanek A, Teper L, Cabala J, Procházka J, Pechar L, Drahota P, Penizek V, Komárek M, Novák M (2012) Geochemical position of $\mathrm{Pb}, \mathrm{Zn}$ and $\mathrm{Cd}$ in soils near the Olkusz mine/ smelter, South Poland: effects of land use type of contamination and distance from pollution source. Environ Monit Assess 184:2517-2536

Chu LM, Cheung KC, Wong MH (1994) Variations in the chemical properties of landfill leachate. Environ Manage 18:105-117

Culbard EB, Thornton I, Watt J, Moorcroft S, Brooks K (1983) Sources and distribution of lead and cadmium in United Kingdom dusts and soils. In: Proceedings of the 4th international conference on heavy metals in the environment, CEP, Edinburgh, pp 426-429

Daskalopoulos E, Badr O, Probert SD (1997) Economic and environmental evaluations of waste treatment and disposal technologies for municipal solid waste. Appl Energy 58(4): 209-255

Daskalopoulos E, Badr O, Probert SD (1998) Municipal solid waste: a prediction methodology for the generation rate and composition in the European Union countries and the United States of America. Resour Conserv Recycl 24:155-166

El-Fadel M, Findikakis AN, Leckie JO (1997) Environmental impacts of solid waste land filling. J Environ Manage 50:1-25

El-Fadel M, Bou-Zeid E, Chahine W, Alayli B (2002) Temporal variation of leachate quality from pre-sorted and baled municipal solid waste with high organic and moisture content. Waste Manage (Oxford) 22:269-282

Erses AS, Onay TT (2003) In situ heavy metal attenuation in landfills under methanogenic conditions. J Hazard Mater B99:159-175

Esakku S, Palanivelu K, Joseph K (2003) Assessment of heavy metals in a municipal solid waste dumpsite. In: Proceedings of the workshop on sustainable landfill management, Chennai, India, pp 139-145

Everett M (1992) The sacred and the profane. Earthwatch, pp 11-13

Fobil JN, Armah NA, Hogarh JN (2008) The influence of institutions and organizations on urban waste collection systems: an analysis of waste collection system in Accra Ghana (1985-2000). J Environ Manage 86(1):262-271

Germani MS, Small M, Zoller WH, Moyers JL (1981) Fractionation of elements during copper smelting. Environ Sci Technol 15:299-304

Gibson MJ, Farmer JG (1983) A survey of trace metal contamination in Glasgow urban soils. In: Proceedings of the 4th international conference on heavy metals in the environment, vol 2, CEP, Edinburgh, pp 1141-1144 
Gidarakos E, Havas G, Ntzamilis P (2005) Municipal solid waste composition determination supporting the integrated solid waste management system in the island of Crete. Waste Manage (Oxford) 26(6):668-679. doi:10.1016/jwasman200507018

Haines RC, Pocock RL (1980) Heavy metal land contamination: background levels and site case histories in the London Borough of Greenwich. Res note 16 Birmingham, Joint Unit for Research on the Urban Environment, University of Aston, Birmingham

Hong KJ, Tokunaga S, Kajiuchi T (2002) Evaluation of remediation process with plant-derived biosurfactant for recovery of heavy metals from contaminated soils. Chemosphere 49:379-387

Iwegbue CMA, Nwajei GE, Ogala JE, Overah CL (2010) Determination of trace metal concentrations in soil profiles of municipal waste dumps in Nigeria. Environ Geochem Health 32:415-430

Jensen DL, Ledin A, Christensen TH (1999) Speciation of heavy metals in landfill-leachate polluted groundwater. Water Res 33:2642-2650

Kabata-Pendias A, Pendias H (2000) Trace elements in soils and plants. CRC Press, New York

Knoll KH (1983) Hygienic problems in dumping composting and incineration of urban refuse. Zentralbl Bakteriol Mikrobiol Hyg 178(1-2):166-173

Kocasoy G (2002) Solid waste management in Turkey. Waste Manag 21

Koerner RM, Soong TY (2000) Leachate in landfills: the stability issues. Geotext Geomembr 18:293-309

Krajewski JA, Szarapińska-Kwaszewska J, Dudkiewicz B, Cyprowski M, Tarkowski S, Kończalik J, Stroszejn-Mrowca G (2001) Assessment of exposure to bioaerosols in workplace ambient air during municipal waste collection and disposal. Med $\mathrm{Pr}$ 52(6):417-422

Kulikowska D, Klimiuk E (2008) The effect of landfill age on municipal leachate composition. Bioresour Technol 99:5981-5985

Kurian J, Rajendiran S, Senthilnathan R, Rakesh M (2012) Integrated approach to solid waste management in Chennai: an Indian metro city. J Mater Cycles Waste Manag 14:75-84

Laurent JP, Olivier F, Gourc JP (2005) Monitoring moisture content in municipal solid waste: results of a preliminary waste under laboratory conditions. International workshop hydro physico mechanics of landfills, Grenoble University, Grenoble

Mandal A, Sengupta D (2006) An assessment of soil contamination due to heavy metals around a coal-fired thermal power plant in India. Environ Geol 51:409-420

Mee DL, Topping G (1998) Black Sea pollution assessment. In: GEF Black Sea environmental programme. Black Sea environmental series, p 10

Mohan S, Gandhimathi R (2009) Solid waste characterisation and the assessment of the effect of dumping site leachate on groundwater quality: a case study. Int J Environ Waste Manag 3(1/2):65-77

Mor S, Ravindra K, Dahiya RP, Chandra A (2005) Leachate characterization and assessment of groundwater pollution near municipal solid Waste landfill site. Environ Monit Assess 118:435-456

Moturi MCZ, Rawat M, Subramanian V (2004) Distribution and fractionation of heavy metals in solid waste from selected sites in the industrial belt of Delhi, India. Environ Monit Assess 95:183-199

Musmeci L, Gucci PM (1997) Health and hygiene aspects of the production of high-quality compost. Ann 1st Super Sanita 33(4):595-603
NEPM (1999) Guidelines on laboratory analysis of potentially contaminated soil. National environmental protection (Assessment of site contamination) measure schedule B (3) 1999

Obiajunwa EI, Pelemo DA, Owalabi SA, Fasai MK, Johnson-Fatokun FO (2002) Characterisation of heavy metal pollutants of soils and sediments around a crude oil production terminal using EDXRF. Nucl Instrum Methods Phys Bull 194:61-64

Olajire AA, Ayodele ET (1998) Heavy metal analysis of solid municipal wastes in the western part of Nigeria. Water Air Soil Pollut 103:219-228

Parry GDR, Johnson MS, Bell RM (1981) Trace metal surveys of soil as a component of strategic and local planning policy development. Environ Pollut Ser B2:97-107

Purves D (1985) Trace-element contamination of the environment. Elsevier, Amsterdam

Rizo OD, Merlo MH, Castillo FE, Lopez JAO (2012) Assessment of metal pollution in soils from a former Havana (Cuba) solid waste open dump. Bull Environ Contam Toxicol 88:182-186

Samuding K (2009) Distribution of heavy metals profile in groundwater system at solid waste disposal site. Eur J Sci Res 37:58-66

Seo DJ, Kimb YJ, Hama SY, Lee DH (2007) Characterization of dissolved organic matter in leachate discharged from final disposal sites which contained municipal solid waste incineration residues. J Hazard Mater 148:679-692

Sharma S, Shah KW (2005) Generation and disposal of solid waste in Hoshangabad. In: Book of proceedings of the 2nd international congress of chemistry and environment Indore, India. pp 749751

Shekdar AV, Krishnawamy KN, Tikekar VG, Bhide AD (1992) Indian urban solid waste management systems - jaded systems in need of resource augmentation. J Waste Manag 12(4):379_ 387

Son HO, Jung MC (2011) Relative extraction ratio (RER) for arsenic and heavy metals in soils and tailings from various metal mines Korea. Environ Geochem Health 33:121-132

Soon YK, Bates TE (1981) Chemical pools of cadmium, nickel and zinc in polluted soil and some preliminary indications of their availability to plants. J Soil Sci 33:477-488

Taoeli BK (2007) The impact of the European landfill directive on waste management strategy and current legislation in Turkey's specially protected areas. Resour Conserv Recycl 52(1):119-135

Tchobanoglous G, Theisen H, Vigil S (1993) Integrated solid waste management: engineering: principles and management issues. McGraw-Hill Inc., New York

Visvanathan C, Trankler J, Joseph K, Chiemchaisri C, Basnayake BFA, Gongming Z (2004) Municipal solid waste management in Asia. Asian regional research program on environmental technology (ARRPET). Asian Institute of Technology publications. ISBN: 974 417-258-1

Waheed S, Siddique N, Hamid Q, Chaudhry MM (2010) Assessing soil pollution from a municipal waste dump in Islamabad, Pakistan: a study by INAA and AAS. J Radioanal Nucl Chem 285:723-732

Yarlagadda PS, Matsumoto MR, VanBenschoten JE, Kathuria A (1995) Characteristics of heavy metals in contaminated soils. J Environ Eng 121(4):276-286

Ziadat AH, Mott H (2005) Assessing solid waste recycling opportunities for closed campuses. Manag Environ Qual 16:250-256 